\title{
GAMBARAN GINGIVITIS PADA IBU HAMIL DI PUSKESMAS TUMINTING KECAMATAN TUMINTING KOTA MANADO
}

\author{
${ }^{1}$ Hendro Yoto \\ ${ }^{2}$ P. S. Anindita \\ ${ }^{3}$ Christy Mintjelungan
Bagian Penyakit Mulut Program Studi Kedokteran Gigi Fakultas Kedokteran Universitas Sam Ratulangi, Sulawesi Utara
Email : hendro.yoto@gmail.com

\begin{abstract}
Gingivitis during pregnancy due to increased concentrations of the hormones estrogen and progesterone. This situation is characterized by the interdental papillae are red, swollen, easily bleeding accompanied by pain causes gingival be particularly sensitive to the toxin and irritants such as plaque and calculus that resulted in inflamed gingiva. This study aims to describe gingivitis in pregnant women in health centers Tuminting based on age, gestational age, educational level, and income level .

Type of research is descriptive research by sampling the sampling Accident pregnant women who come checkups at health centers and pregnant women who are subject to the criteria that are in trimester II and III trimester .

The results showed the distribution by age 21-30 years ( $51 \%$ ), gingival status based on gestational age at second and third trimester with mild inflammation ( $60 \%$ ), gingival status by finishing primary education level inflamsi mild ( $62.5 \%)$ and in graduated from college reached ( $100 \%$ ), gingival status by income level $>1$ million per month ( $65.78 \%)$ and income pernulan 1-5 million ( $47.05 \%)$. Conclusion gingival status by measuring gingival index , gingival normal 14 ( $25.4 \%$ ) , 33 mild inflammation ( $60 \%$ ), moderate inflammation 6 ( $11 \%$ ), and 2 severe inflammation ( $3.6 \%$ ). Need for cooperation between gynecologists and dentists in dealing with oral and dental problems in pregnant women .
\end{abstract}

Keywords : Pregnancy, Gingivitis

\begin{abstract}
Abstrak
Gingivitis pada saat kehamilan disebabkan oleh peningkatan konsentrasi hormon estrogen dan progesteron. Keadaan ini ditandai dengan papila interdental yang memerah, bengkak, mudah berdarah disertai rasa sakit menyebabkan gingiva menjadi sensitif khususnya terhadap toksin maupun iritan seperti plak dan kalkulus yang mengakibatkan gingiva mengalami peradangan. Penelitian ini bertujuan untuk mengetahui gambaran gingivitis pada ibu hamil di Puskesmas Tuminting berdasarkan usia, usia kehamilan, tingkat pendidikan, dan tingkat penghasilan.

Jenis penelitian yaitu penelitian deskriptif dengan cara pengambilan sampel Accident sampling yaitu ibu hamil yang datang memeriksakan kehamilannya di Puskesmas dan ibu hamil yang menjadi subjek dengan kriteria berada pada trimester II dan trimester III.

Hasil penelitian menunjukkan distribusi berdasarkan usia 21-30 tahun (51\%), status gingiva berdasarkan usia kehamilan pada trimester II dan III dengan inflamasi ringan (60\%), status gingiva berdasarkan tingkat pendidikan tamat SD inflamsi ringan $(62,5 \%)$ dan pada tamat perguruan tinggi mencapai (100\%), status gingiva berdasarkan tingkat penghasilan $>1$ juta perbulan $(65,78 \%)$ dan penghasilan 1-5 juta pernulan $(47,05 \%)$. Kesimpulan status gingiva berdasarkan indeks pengukuran gingiva, 14 orang gingiva normal $(25,4 \%), 33$ orang inflamasi ringan $(60 \%), 6$ orang inflamasi sedang $(11 \%)$, dan 2 orang inflamasi berat $(3,6 \%)$. Perlu adanya kerja sama antara dokter ahli kandungan dan dokter gigi dalam menangani masalah gigi dan mulut pada ibu hamil.
\end{abstract}

Kata kunci: Kehamilan, Gingivitis 
Wanita memiliki kebutuhan kesehatan yang unik. Dalam siklus hidupnya, pada masa tertentu wanita memerlukan perhatian yang lebih untuk menjaga kesehatannya, yakni saat pubertas, kehamilan dan menopause. Kehamilan merupakan proses alamiah yang menyebabkan terjadinya perubahan pada wanita yang mencakup perubahan fisiologis dan psikologis. Perubahan-perubahan saat kehamilan dapat memengaruhi kesehatan sistem didalam tubuh dan mengakibatkan terjadinya perubahan pada beberapa bagian tubuh termasuk rongga mulut. Salah satu perubahan yang terjadi pada masa kehamilan yaitu terjadinya perubahan hormonal yang menyebabkan terjadinya respon plak berlebih dan mengakibatkan terjadinya penyakit periodontal. ${ }^{1}$ Kesehatan gigi dan mulut yang buruk akibat perilaku yang salah pada saat kehamilan dapat menyebabkan penyakit periodontal dan ibu hamil dengan keadaan periodontal yang buruk dapat beresiko tinggi. ${ }^{1}$ Secara klinis terjadi perubahan inflamatori pada gingiva ibu hamil. Penyakit periodontal yang sering terjadi ialah gingivitis pada saat kehamilan. Gingivitis pada saat kehamilan ditemukan pada $80-100 \%$ ibu hamil. Gingivitis umumnya terjadi pada trimester kedua kehamilan dan secara progresif meningkat dengan bertambahnya usia kehamilan. $^{2}$

Gingivitis pada saat kehamilan disebabkan oleh peningkatan konsentrasi hormon estrogen dan progesteron di dalam darah. Adanya perubahan hormonal disertai dengan perubahan vaskuler menyebabkan gingiva menjadi sensitif khususnya terhadap toksin maupun iritan lainnya, seperti plak dan kalkulus yang mengakibatkan gingiva mengalami peradangan. Keadaan ini ditandai dengan papila interdental yang memerah, bengkak, mudah berdarah dan disertai rasa sakit. $^{2}$ Gingivitis pada saat kehamilan merupakan kondisi reversibel yang dapat bersifat lokal atau menyeluruh. Perubahan hormonal dan vaskuler yang dihubungkan dengan kehamilan dapat menyebabkan respon gingiva yang berlebihan terhadap plak bakteri. Kehamilan dapat memperberat kondisi yang telah ada sebelumnya. Bila seorang ibu hamil telah mengalami infeksi gingiva sebelumnya, kemungkinan besar infeksi gingiva akan bertambah buruk selama kehamilan berlangsung terutama bila tanpa dilakukan perawatan. ${ }^{3}$
Penelitian terbaru menunjukkan hubungan antara gingivitis pada saat kehamilan dengan kelahiran prematur disertai berat bayi lahir rendah (BBLR). Bakteri berlebihan yang merupakan penyebab gingivitis dapat masuk ke dalam aliran darah. Bila hal ini terjadi, bakteri dapat berpindah ke rahim, memicu produksi senyawa kimia prostaglandin yang menyebabkan terjadinya kontraksi uterus sehingga menginduksi kelahiran prematur. Gingivitis juga dapat menyebabkan keterlambatan dalam pertumbuhan bayi dan bahkan kematian bayi. ${ }^{3,4}$ Penelitian Offenbacher pada ibu hamil mendapati faktor risiko terjadinya bayi BBLR kurang bulan, dimana status gingiva dari ibu yang melahirkan bayi BBLR kurang bulan lebih buruk dari ibu yang melahirkan bayi normal. Hal ini karena kurangnya pengetahuan ibu hamil mengenai hubungan kehamilan dengan kesehatan gigi dan mulut. Perilaku kunjungan ke dokter gigi dipengaruhi oleh beberapa faktor, seperti faktor individu, status ekonomi, dan pengetahuan mengenai hubungan kehamilan dengan kesehatan gigi dan mulut. ${ }^{5}$

Balai Data Surveilens dan Sistem Informasi Kesehatan Dinas Kesehatan Provinsi Sulawesi Utara mencatat bahwa dari 43.302 ibu hamil di 15 kabupaten/ kota, 7.814 ibu hamil beresiko tinggi untuk melahirkan. Sebanyak 5.407 dari jumlah tersebut atau $71,7 \%$ ibu hamil resiko tinggi ditangani, sehingga masih tersisa sekitar 28,3\% kasus yang belum ditangani yang tersebar di seluruh puskesmas yang ada di Sulawesi Utara. ${ }^{6}$

Puskesmas Tuminting merupakan puskesmas yang letaknya berada di pinggiran kota Manado. Sosial ekonomi masyarakatnya rendah karena sebagian besar berprofesi sebagai nelayan tradisional. Penelitian tentang gingivitis pada saat kehamilan juga belum pernah dilakukan di Puskesmas Tuminting. Penyuluhan kesehatan tentang kesehatan gigi dan mulut pada saat kehamilan juga kurang dilakukan. Berdasarkan penjelasan di atas penulis merasa tertarik melakukan penelitian untuk melihat bagaimana gambaran gingivitis pada ibu hamil di Puskesmas Tuminting Kecamatan Tuminting Kota Manado.

\section{METODE PENELITIAN}

Jenis penelitian yang dilakukan yaitu penelitian deskriptif. Penelitian dilaksanakan di Puskesmas Tuminting selama 2 minggu pada bulan Maret 2013. Populasi pada 
penelitian ini yaitu ibu hamil yang berkunjung ke Puskesmas Tuminting. Besar sampel dalam penelitian ini yaitu 57 orang ibu hamil yang berkunjung ke poli KIA di Puskesmas Tuminting.

a. Kriteria inklusi:

1. Ibu hamil dengan usia kehamilan berada pada trimester kedua dan ketiga

2. Ibu hamil sehat jasmani dan rohani

3. Bersedia menandatangani informed consent

4. Bersikap kooperatif selama pengambilan data

b. Kriteria eksklusi:

1. Ibu hamil yang datang kedua kali dalam bulan penelitian dengan usia kehamilan sama

2. Ibu hamil yang kehilangan sebagian besar gigi atau edentulous

Sampel pada penelitian ini diambil dengan metode accidental sampling, yaitu hanya ibu hamil yang datang memeriksakan kehamilannya di Puskesmas Tuminting dan sesuai dengan kriteria inklusi dan eksklusi didapatkan jumlah subjek 55 orang ibu hamil.

Ibu hamil yaitu Seorang wanita yang mempunyai fetus atau embrio yang dikandung di dalam tubuh (WHO). ${ }^{7}$ Gingivitis saat kehamilan yaitu pembengkakan pada gingiva di seluruh rongga mulut dengan mempunyai tanda-tanda klinis berupa pembengkakan dan warna gingiva terlihat lebih merah dari biasanya. Izin penelitian dimintakan pada Program Studi Kedokteran Gigi Fakultas Kedokteran Universitas Sam Ratulangi, surat izin kemudian diberikan pada Puskesmas Tuminting melalui badan administrasi Puskesmas Tuminting dan izin penelitian yang dimintakan kepada subjek penelitian. Proses pengumpulan data dilakukan oleh tim yang terdiri dari 3 orang dan dikordinir oleh penulis. Penelitian dilakukan pada saat Poli KIA dibuka yaitu pada hari Selasa, Rabu dan Kamis dengan memeriksa rongga mulut ibu hamil yang datang ke Puskesmas Tuminting dimulai pada pukul 08.00 - selesai. Sebelum dilakukan penelitian pada ibu hamil, pertama-tama dilakukan koordinasi dengan petugas yang ada di Poli KIA. Setelah ibu hamil mendaftar dan diketahui usia kehamilannya, ibu hamil yang masuk dalam sampel diarahkan untuk ke Poli Gigi sebelum memeriksakan kehamilanya.
Selanjutnya ibu hamil diberikan penjelasan tentang maksud penelitian kemudian diminta persetujuan dari ibu hamil melalui informed consent. Pemeriksaan pada ibu hamil dilakukan dengan menggunakan alat diagnostik dan dental probe. Selanjutnya dilakukan pencatatan pada formulir pemeriksaan mengenai ada atau tidaknya gingivitis pada saat kehamilan. Ibu hamil yang berkunjung kedua kali di puskesmas dalam bulan penelitian tetapi usia kehamilannya masih sama, tidak akan dilakukan pemeriksaan lagi. Ibu hamil yang datang 2 kali dalam bulan penelitian dengan usia kehamilan berbeda tapi masih termasuk dalam sampel, yang diambil adalah data pada pemeriksaan kedua. Ibu hamil yang kehilangan sebagian besar gigi atau edentulous tidak akan dilakukan pemeriksaan. Pengolahan data dilakukan dengan cara manual dan ditabulasikan, yakni semua data yang terkumpul diolah, diperiksa kembali apakah semua data telah lengkap, selanjutnya dilakukan pengkodean dalam daftar berdasarkan jumlah pasien dan dilakukan pengolahan data. Analisis data dilakukan dengan menghitung persentase ibu hamil yang datang memeriksakan kehamilannya terkait masalah gingivitis saat kehamilan. Penyusunan pada tabel dikelompokkan berdasarkan usia kehamilan, pendidikan dan penghasilan.

\section{HASIL PENELITIAN}

Penelitian dilaksanakan di Poliklinik KIA Puskesmas Tuminting Kecamatan Tuminting Jalan Sindulang I Kota Manado. Puskesmas Tuminting sebelah Utara berbatasan dengan Kecamatan Bunaken, Timur dengan Kecamatan Mapanget, Barat dengan Teluk Manado, dan Selatan dengan Kecamatan Singkil dan Wenang. Kecamatan Tuminting meliputi Kelurahan Karang Ria, Kelurahan Islam, Kelurahan Sindulang I/II, Kelurahan Tuminting, Kelurahan Mahawu, Kelurahan Sumompo, Kelurahan Maasing dan Kelurahan Tumumpa I/II. Kepala Puskesmas Tuminting dengan jumlah tenaga kesehatan yaitu 4 orang dokter umum, 1 orang dokter gigi, 6 orang bidan, 1 orang SPK kebidanan, 18 perawat, 4 orang pekarya, 2 orang asisten apoteker, 1 orang kesehatan masyarakat, 2 orang sanitarian, 2 orang gizi, 2 orang perawat gigi, dan 1 orang staf administrasi. Sarana dan prasarana penunjang yaitu 7 PKM pembantu 
dan 48 posyandu. Instalasi pelayanan terdiri dari rawat inap, rawat jalan, rawat darurat, rawat intensif dan lain-lain.
Subjek pada penellitian ini sebanyak 55 orang dan dapat dibedakan berdasarkan usia (Tabel 1).

Tabel 1. Distribusi subjek penelitian berdasarkan usia.

\begin{tabular}{ccc}
\hline $\begin{array}{c}\text { Usia } \\
\text { (Tahun) }\end{array}$ & $\mathrm{n}$ & $(\%)$ \\
& & \\
\hline $15-20$ & 12 & 21,8 \\
$21-30$ & 28 & 51 \\
$31-40$ & 15 & 27,2 \\
\hline Total & & 100 \\
\hline
\end{tabular}

Data pada Tabel 1. menunjukkan bahwa sebagian besar subjek penelitian berusia 21 30 tahun yaitu $51 \%$ (28 orang).
Subjek pada penelitian ini dikelompokkan berdasarkan usia kehamilan (Tabel 2).

Tabel 2. Distribusi subjek penelitian berdasarkan usia kehamilan

\begin{tabular}{ccc}
\hline Usia Kehamilan & $\mathrm{n}$ & $(\%)$ \\
\hline Trimester II & 15 & 27,2 \\
Trimester III & 40 & 72,8 \\
\hline Total & & 100 \\
\hline
\end{tabular}

Data pada Tabel 2. menunjukkan bahwa sebagian besar subjek penelitian ada pada usia kehamilan trimester III $(72,8 \%)$.
Subjek penelitian juga dikelompokkan berdasarkan tingkat pendidikan (Tabel 3).

Tabel 3. Distribusi subjek penelitian berdasarkan tingkat pendidikan

\begin{tabular}{lcc}
\hline \multicolumn{1}{c}{ Tingkat Pendidikan } & $\mathrm{n}$ & $(\%)$ \\
\hline Tidak Tamat SD & 0 & 0 \\
Tamat SD & 8 & 14,5 \\
Tamat SMP & 11 & 20 \\
Tamat SMA & 33 & 60 \\
Tamat Perguruan & 3 & 5,5 \\
Tinggi & & \\
\hline \multicolumn{1}{c}{ Total } & 55 & 100 \\
\hline
\end{tabular}

Data pada Tabel 3. menunjukan bahwa sebagian besar subjek berada pada tingkat pendidikan tamat SMA yaitu berjumlah 33 orang $(60 \%)$ dan tidak ada yang tidak tamat SD.
Subjek penelitian dibedakan berdasarkan tingkat penghasilan (Tabel 4). 
Tabel 4. Distribusi subjek penelitian berdasarkan tingkat penghasilan

\begin{tabular}{ccc}
\hline Tingkat Penghasilan & $\mathrm{n}$ & $(\%)$ \\
\hline$<1$ juta perbulan & 38 & 69,1 \\
1 - 5 juta perbulan & 17 & 30,9 \\
3 - 5 juta perbulan & 0 & 0 \\
\hline Total & 55 & 100
\end{tabular}

Hasil penelitian menunjukkan bahwa paling banyak subjek dengan penghasilan kurang dari 1 juta perbulan yaitu terdapat 38 orang $(69,1 \%)$ dan tidak ada subjek yang berpenghasilan $3-5$ juta perbulan.

Hasil penelitian mengenai gambaran gingivitis pada saat kehamilan bervariasi, didapatkan ada yang memiliki status gingiva normal, ringan, sedang, dan berat (Tabel 5).

Tabel 5. Distribusi subjek penelitian berdasarkan pengukuran indeks gingiva

\begin{tabular}{ccc}
\hline Status Gingiva & $\mathrm{n}$ & $(\%)$ \\
\hline Normal & 14 & 25,4 \\
Inflamasi ringan & 33 & 60 \\
Inflamasi sedang & 6 & 11 \\
Inflamasi berat & 2 & 3,6 \\
\hline Total & 55 & 100 \\
\end{tabular}

Data pada Tabel 5 menunjukkan dari 55 subjek penelitian sebagian besar mengalami inflamasi ringan yaitu 33 orang $(60 \%)$ dan hanya terdapat 2 orang $(3,6 \%)$ ibu hamil

Distribusi status gingiva dikelompokkan berdasarkan usia kehamilan (Tabel 6). dengan inflamasi berat.

Tabel 6. Distribusi status gingiva berdasarkan usia kehamilan

Usia Kehamilan

\begin{tabular}{ccccc}
\cline { 2 - 5 } Status Gingiva & Trimester II & $\%$ & Trimester III & $\%$ \\
& $\mathrm{n}$ & & $\mathrm{n}$ & \\
\hline Normal & 4 & 26,8 & 10 & 25 \\
Inflamasi ringan & 9 & 60 & 24 & 60 \\
Inflamasi sedang & 2 & 13,4 & 4 & 10 \\
Inflamasi berat & 0 & 0 & 2 & 5 \\
\hline Total & 15 & 100 & 40 & 100 \\
\hline
\end{tabular}

Data pada Tabel 6. menunjukkan pada usia kehamilan trimester II dan trimester III yang paling banyak terjadi yaitu inflamasi ringan masing-masing sebesar 60\% ibu hamil. Pada tabel di atas terlihat tidak ada perbedaan yang menonjol pada jumlah persentase subjek inflamasi ringan pada trimester II sama dengan jumlah persentase subjek inflamasi ringan pada trimester III dan pada trimester II tidak ada yang mengalami inflamasi berat.

Distribusi status gingiva juga dikelompokkan berdasarkan tingkat pendidikan (Tabel 7). 
Tabel 7. Distribusi status gingiva berdasarkan tingkat pendidikan

Tingkat Pendidikan (\%)

\begin{tabular}{cccccc}
\cline { 2 - 6 } Status Gingiva & $\begin{array}{c}\text { Tidak } \\
\text { Tamat SD }\end{array}$ & $\begin{array}{c}\text { Tamat } \\
\text { SD }\end{array}$ & $\begin{array}{c}\text { Tamat } \\
\text { SMP }\end{array}$ & $\begin{array}{c}\text { Tamat } \\
\text { SMA }\end{array}$ & $\begin{array}{c}\text { Tamat Perguruan } \\
\text { Tinggi }\end{array}$ \\
\hline Normal & 0 & 0 & 0 & 42,43 & 0 \\
Inflamasi ringan & 0 & 62,5 & 91 & 45,47 & 100 \\
Inflamasi sedang & 0 & 25 & 9 & 9,1 & 0 \\
Inflamasi berat & 0 & 12,5 & 0 & 3 & 0 \\
\hline Total & 0 & 100 & 100 & 100 & 100 \\
\hline
\end{tabular}

Data pada Tabel 7. menunjukkan bahwa pada semua tingkat pendidikan persentase terbesar ada pada kasus inflamasi ringan dengan tingkat pendidikan tamat SD yaitu $62,5 \%$ dan inflamasi ringan ibu hamil dengan tingkat pendidikan tamat perguruan tinggi paling banyak yaitu mencapai 100\%. Gingiva normal Tabel 8. Distribusi status gingiva berdasarkan tingkat penghasilan

\begin{tabular}{cccc}
\hline & \multicolumn{3}{c}{ Tingkat Penghasilan (\%) } \\
\cline { 2 - 4 } Status Gingiva & $<1$ juta & $1-5$ juta & $>5$ juta \\
\hline Normal & 23,68 & 29,42 & 0 \\
Inflamasi ringan & 65,78 & 47,05 & 0 \\
Inflamasi sedang & 7,90 & 17,64 & 0 \\
Inflamasi berat & 2,64 & 5,89 & 0 \\
\hline Total & 100 & 100 & 0 \\
\hline
\end{tabular}

Tabel 8. menunjukkan bahwa sebagian besar mengalami inflamasi ringan baik pada subjek dengan tingkat penghasilan kurang dari 1 juta perbulan $(65,78 \%)$ maupun yang berpenghasilan $1-5$ juta perbulan $(47,05 \%)$. Tidak ada subjek dengan penghasilan lebih dari 5 juta perbulan.

\section{PEMBAHASAN}

Jumlah subjek penelitian dalam penelitian ini 55 orang ibu hamil. Berdasarkan usia ibu hamil (Tabel 1) jumlah subjek penelitian yang paling banyak pada penelitian ini terdapat pada usia 21 - 30 tahun yaitu berjumlah 28 orang (51\%). Berdasarkan usia kehamilan (Tabel 2) dilakukan pemeriksaan pada usia kehamilan trimester II dan trimester III karena gingivitis pada saat kehamilan mulai terlihat pada awal hanya dijumpai pada tingkat pendidikan tamat SMA dengan persentasi mencapai $42,43 \%$.

Distribusi status gingiva berdasarkan usia kehamilan dapat dilihat pada (Tabel 8). 
Ganesh dkk sama-sama mengalami kenaikan pada subjek dengan dengan tingkat pendidikan tamat SMA. Hal ini mungkin dipengaruhi oleh subjek yang datang sebagian besar dengan tingkat pendidikan tamat SMA.

Distribusi subjek penelitian berdasarkan tingkat penghasilan (Tabel 4) menunjukkan, bahwa subjek sebagian besar mempunyai penghasilan kurang dari 1 juta perbulan yaitu mencapai persentase $69,1 \%$ dan tidak terdapat subjek dengan penghasilan lebih dari 5 juta rupiah. Penelitian Wandera dkk pada ibu hamil di Uganda menunjukkan adanya keterkaitan antara indeks kekayaan dengan keadaan periodontal, tingkat penghasilan dapat mempengaruhi keadaan gingiva seseorang, kaitan dan pembahasan lainnya terdapat pada tabel $8 .^{25}$

Pengukuran indeks gingiva pada subjek penelitian menurut Loe dan Silness (Tabel 5) menunjukkan, bahwa sebagian besar ibu hamil mengalami inflamasi ringan yaitu berjumlah $(60 \%)$. Hasil ini sedikit berbeda dengan penelitian yang dilakukan oleh Nassrawin dkk tahun 2002 di King Husein Medical Center Jordan, yaitu dari total 360 subjek yang diteliti $26 \%$ yang mengalami inflamasi ringan, $70 \%$ inflamasi sedang, dan $4 \%$ inflamasi berat. Perbedaan hasil penelitian ini mungkin dipengaruhi oleh tempat penelitian yang dilakukan di Medical Center. Pemeriksaan pasien dilakukan di klinik periodontal namun pasien diambil dari bagian obstetri dan ginekologi, hal ini yang menyebabkan persentase pada penlitian yang dilakukan oleh Nassrawin berbeda dengan peneliti yang hanya melakukan penelitian di puskesmas, dimana ibu hamil yang datang ke Puskesmas hanya untuk memeriksakan kehamilan. ${ }^{26}$

Distribusi status gingiva berdasarkan usia kehamilan (Tabel 6) menunjukkan bahwa ibu hamil dengan usia kehamilan trimester III memiliki indeks gingiva yang lebih tinggi. Pada usia kehamilan trimester II dengan status ginigiva normal terdapat $26,8 \%$ dan pada trimester III mengalami penurunan yaitu hanya terdapat $25 \%$, inflamasi ringan pada trimester II dan trimester III sama-sama terdapat $60 \%$ inflamasi, pada inflamasi sedang di trimester II mengalami sedikit peningkatan yaitu terdapat $13,4 \%$ sedangkan pada usia kehamilan trimester III dengan inflamasi sedang hanya mencapai $10 \%$ dan hanya pada usia kehamilan trimester III yang terdapat inflamasi berat yaitu 5\%. Penelitian Ganesh dkk di Government Maternity Hospital juga mendapati hasil indeks gingiva yang tinggi pada usia kehamilan trimester III yaitu mencapai $54,8 \%$. Hal ini terjadi karena pada usia kehamilan trimester III merupakan puncak terjadinya gingivitis pada kehamilan. ${ }^{24}$

Distribusi status gingiva berdasarkan tingkat pendidikan (Tabel 7) tidak menunjukkan bahwa ibu hamil dengan tingkat pendidikan yang lebih tinggi memiliki indeks gingiva yang lebih tinggi dimana ibu hamil dengan tingkat pendidikan tamat perguruan tinggi mencapai persentase hingga $100 \%$ pada indeks gingiva dengan inflamasi ringan sedangkan ibu hamil dengan tingkat pendidikan tamat SD hanya $62,5 \%$. Hal ini berbeda dengan hasil penelitian status gingiva pada ibu hamil dengan tingkat pendidikan yang dilakukan oleh Tanii dkk dan Sarlati dkk dimana subjek dengan tingkat pendidikan tamat SD terdapat (50\%) dengan status gingiva inflmasi ringan, pada tingkat pendidikan tamat SMP terdapat $(63,6 \%)$ dengan status gingiva inflamasi ringan, pada tingkat pendidikan tamat SMA terdapat $(48,4 \%)$ dengan status gingiva inflamasi ringan. Pada penelitian Tanii dkk dan Sarlati dkk terlihat perbandingan antara tingkat pendidikan yang lebih rendah memiliki persentase yang lebih tinggi daripada tingkat pendidikan yang lebih tinggi memiliki persentase yang lebih rendah. Dalam penelitiannya juga menyatakan bahwa terjadinya inflamasi gingiva pada ibu hamil berhubungan dengan tingkat pendidikan yang dimiliki ibu hamil tersebut. Seperti yang telah penulis sebutkan sebelumnya bahwa adanya perbedaan hasil penelitian Ganesh dkk dengan penelitian juga dipengaruhi oleh perbedaan tingkat pendidikan dari subjek penelitian. Pada penelitian yang dilakukan Ganesh dkk terdapat sebanyak $(6,7 \%)$ yang tamat $\mathrm{SD},(17,8 \%)$ tamat SMP, $(38,9 \%)$ tamat SMA, dan $(26,5 \%)$ tamat perguruan tinggi. ${ }^{27,28,29}$

Distribusi status gingiva berdasarkan tingkat penghasilan (Tabel 8) menunjukkan bahwa ibu hamil dengan penghasilan yang lebih tinggi memiliki indeks gingiva yang lebih tinggi dibandingkan dengan penghasilan yang lebih rendah. Hasil penelitian yang dilakukan peneliti berbeda dengan penelitian yang dilakukan oleh Wandera dkk pada ibu hamil di Uganda. Ibu hamil yang memiliki kekayaan lebih tinggi cenderung memiliki kondisi jaringan periodontal yang lebih baik 
dibandingkan dengan ibu hamil yang memiliki kekayaan lebih rendah. ${ }^{32,33}$ Perbedaann hasil penelitian yang didapatkan oleh peneliti dan hasil yang didapatkan oleh Wandera dkk mungkin dipengaruhi oleh tingkat penghasilan dari subjek yang diteliti dan tempat penelitian. Di Uganda perbedaan status sosial ekonominya masih terlihat karena Uganda merupakan negara yang sedang berkembang. ${ }^{25}$

\section{SIMPULAN DAN SARAN}

\section{A. Kesimpulan}

Berdasarkan hasil penelitian gambaran gingivitis pada saat kehamilan di Puskesmas Tuminting Kecamatan Tuminting Kota Manado, dapat disimpulkan:

1. Status gingiva berdasarkan pengukuran indeks gingiva paling banyak dengan inflamasi ringan yaitu 33 orang (60\%).

2. Berdasarkan usia kehamilan menunjukkan bahwa ibu hamil dengan usia kehamilan trimester III memiliki indeks gingiva lebih tinggi karena merupakan puncak terjadinya gingivitis pada saat kehamilan.

3. Status gingiva berdasarkan tingkat pendidikan menunjukkan bahwa ibu hamil dengan tingkat pendidikan yang lebih tinggi tidak bisa menjamin seseorang memiliki indeks gingiva yang lebih baik.

4. Tingkat penghasilan juga tidak bisa menunjukkan bahwa ibu hamil dengan penghasilan lebih tinggi gingivanya akan lebih baik dibandingkan ibu hamil dengan penghasilan lebih rendah.

\section{B. Saran}

Berdasarkan kesimpulan dan hasil penelitian di atas, beberapa hal yang perlu penullis sarankan yaitu:

1. Perlu diadakan penelitian yang lebih lanjut terhadap gambaran status gingiva pada ibu hamil di puskesmas-puskesmas lain yang ada di Kota Manado. Hal ini dapat berguna sebagai data pembanding terhadap hasil penelitian ini.

2. Penelitian yang lebih lanjut juga diperlukan untuk meneliti hubungan pengetahuan, perilaku dan status gingiva pada ibu hamil yang dimulai dari usia kehamilan trimester I hingga trimester III pada ibu hamil, meskipun rentang waktu yang cukup lama. Namun hasil yang akan didapatkan lebih akurat dibandingkan penelitian ini.

3. Perlu adanya kerja sama antara dokter ahli kandungan dan dokter gigi dalam menangani masalah gigi dan mulut pada ibu hamil. Kehamilan merupakan salah satu faktor resiko terjadinya gangguan pada gingiva yang diakibatkan oleh adanya perubahan hormonal yang menyebabkan respon plak berlebih, sehingga nantinya dapat mencegah terjadi kerusakan jaringan periodontal lebih lanjut.

\section{DAFTAR PUSTAKA}

1. Ajwani S, Bhole S, Blinkhorn A, Elli S, George A, Johnson M. Promoting oral health during pregnancy: Current evidence and implications for Australian midwives. J Clin Nurs. 2010; 19 (23-24): p . 3324 - 33. Available from: URL: www.ncbi.nlm.nih.gov/pubmed/2095548 $\underline{3}$

2. Ekaputri N, Sjahruddin FD. Hubungan perilaku wanita hamil dalam membersihkan gigi dan mulut dengan kedalaman poket periodontal selama masa kehamilan. Majalah Ilmiah Kedokteran Gigi 2005; 20 (62): h. 90 - 7.

3. Singh S, et al. Periodontal disease and adverse pregnancy outcome. Pakistan oral \& dental journal 2011; 31. p. 165.

4. Mayberry LJ, Russell SL. Pregnancy and oral health: A review and recommendations to reduce gaps in practice and research. MCN Am J Matern Child Nurs; 2008; 33 (1): p. $32-7$.

5. Offenbacher S, Jared HL, O'Reilly PG, Wells SR, Salvi GE, Lawrence HP et.al. Potential pathogenic mechanism of periodontitis associated pregnancy complication. Ann Periodontol 1998; 13 : p. 233-47.

6. Balai data surveilens dan sistem informasi kesehatan Dinas Kesehatan Propinsi Sulawesi Utara, profil kesehatan Propinsi Sulawesi Utara 2010, edisi 2011. 
7. Rai B, Kaur J, Kharb S. Pregnancy gingivitis and periodontitis and its systemic effect. The internet $\mathbf{J}$ of Debt Science. 2009; 6 (2).p.1-5. Available from:URL:

http://www.ispub.com/journal/theinternet-journal-of-dentalscience/volume-6-number-2/pregnancygingivitis-and-periodontitis-and-itssystemic-effect.html (dikunjungi pada 23 Maret 2012).

8. Claas BM, Loschmann LE, Jeffreys M. Self-reported oral health care and access to oral health information among pregnant women in Wellington, New Zealand. Journal of the New Zealand Medical Association, 29 juli 2011 (v)124 no.1339. Available from:URL:http://journal.nzma.org.nz/jour nal/124-1339/4781 (dikunjungi pada 20 Maret 2012).

9. Newman MG, Takei HH, Klokkevold PR. Carranza FA. Carranza's clinical periodontology. $10^{\text {th }}$ ed. Missouri: Saunders-Elsevier; 2006: p. $636-47$.

10. Ganesh A, Ingle NA, Chaly PE, Reddy VC. A survey on dental knowledge and gingival health of pregnant women attending government maternity hospital chennai. Journal Oral Health Comm Dent 2011; 5 (1): p. $24-30$.

11. Wandera M, Engebretsen IMS, Okullo I, Tumwine JK, Astrom AN. Sociodemographic factors related to periodontal status and tooth loss of pregnant women in mbale district, Uganda. BMC Oral Health 2009, 9: 18: p. $1-11$.

12. Nassrawin N, Barakat M. Prevalence of gingival disease in a population of pregnant women. JRMS December 2002; (9) 2: p. $12-15$

13. World health organization. A guide to oral health epidemiological investigations [dikunjungi pada 30 Maret 2013]. Available from URL: http://whqlibdoc.who.int/hq/1979/ORH_E PID GUIDE 79.1.pdf.

14. Tanii DQ, Habashneh R, Hammad MM, Batieha A. The periodontal status of pregnant women and its relationship with socio-demographic and clinical variables [dikunjungi pada 30 Maret 2013]. Available from URL:http//www.ncbi.nlm.nih.gov/pubme d?term=The $\% 20$ periodontal $\% 20$ status $\% 2$ 0of\%20pregnant $\% 20$ women $\% 20$ and $\% 20 \mathrm{i}$ ts\%20relationship\%20with\%20sociodem ographic\%20and\%20cilinical\%20variable s.

15. Sarlati F, Akhondi N, Jahanbaskhsh N. Effect of general health and sociocultural variables on periodontal status of pregnant women. [dikunjungi pada 31 Mret 2013]. Available from URL: http://www.ncbi.nlm.nih.gov/pubmed/153 $\underline{68876}$. 